3. Ukaz Prezydenta Ukrainy № 240/2016 «Pro rishennia Rady natsionalnoi bezpeky i oborony Ukrainy vid 20 travnia 2016 roku «Pro Stratehichnyi oboronnyi biuleten Ukrainy»« vid 6 chervnia 2016 r. URL: http://zakon.rada.gov.ua/laws/show/240/2016 (data zvernennia: 11.11.2020) (Presidential Decree of Ukraine No.240/2016 «On decision of the National Security and Defence Council of Ukraine dd May 20, 2016 «On Strategic Defence Bulletin of Ukraine». URL: http://zakon.rada.gov.ua/laws/show/240/2016 (accessed on: 11.11.2020)).

DOI https://doi.org/10.30525/978-9934-26-005-6-9

\title{
УПРАВЛІНСЬКА КУЛЬТУРА ЯК СОЦІОКУЛЬТУРНИЙ МЕХАНІЗМ ПЕРЕХОДУ ДО ПУБЛІЧНОГО УПРАВЛІННЯ В УКРӒ̈НІ
}

\author{
Пержун В. В. \\ кандидат сочіологічних наук, дочент, \\ докторант \\ Начіональної академії державного управління \\ при Президентові України \\ м. Чернівиі, Україна
}

Соціокультурна сфера відображає й направлена на виявлення різноманітних характеристик життєдіяльності людини i соціально-професійних груп суспільства; навіть більше, координує, направляє і певним чином обмежує людей у поглядах i практичних кроках перетворення суспільних відносин. У нашому випадку це стосується управлінської культури як соціокультурного механізму, що сприяє переходу до результативного публічного управління.

У публічному управлінні має, на нашу думку, формуватися управлінська культура, що базується на спільних інтересах, ідеалах, цінностях і певній управлінській поведінці. Але така 
постановка питання не означає, що всі повинні бути фізично, культурно і духовно однакові, проте основоположні якості й ознаки управлінської культури - освіта, знання й інтелект, відповідальність, толерантність, управлінська дисципліна, колективізм і взаємодопомога у роботі, повага до колег тощо мають переважати. Звичайно, сучасна реальність вносить свої поправки і корективи в цьому, оскільки повсякчас відбуваються зміни, які стосуються саме основ управлінської культури як механізму переходу i становлення публічного управління в Україні. До таких основ ми відносимо: можлива зміна своїх переконань, ідей, підходів до роботи та стосунків 3 колегами і оточенням; переосмислення у процесі управлінської роботи поведінки, норм і цінностей управлінської діяльності; зміна колективних відносин та індивідуальних стосунків; дещо інший погляд на життєві й професійно-статусні перспективи подальшої управлінської діяльності і т. д.

Перераховані нормативно-управлінські зміни створюють певну діалогову багатомірну модель самої культури, яку можна назвати соціокультурною динамікою. Мова йде про видозміну управлінської культури, де поряд 3 класичними якостями та ознаками утверджуються нові: вивчення та використання в публічному управлінні новітніх управлінських технологій; системна переорієнтація від старого командноадміністративного, наказового управління до сучасних, дієвих управлінських відносин на основі результативного соціального діалогу держави і громадянського суспільства; впровадження ефективних правових й управлінських регуляторів у публічному управлінні; духовно-моральне оздоровлення суспільства; створення умов для підготовки сучасного покоління менеджерів публічного управління тощо [3, с. 110-111].

Основоположні засади управлінської культури також зумовлюють дещо по-іншому аналізувати й розуміти категорію «цінності» у публічному управлінні. 3 цього приводу М. Вебер наполягав на думці, що певні норми та цінності, що властиві суспільству відображають його спосіб і властивості життя, поведінки, практичних дій. Він писав, що це «культурний код, який допомагає краще зрозуміти специфіку норм життєдіяльності суспільства» [1, с. 478]. Стосується таке й 
управлінської роботи, оскільки вона проходить у суспільстві, впливає на розвиток суспільства, а суспільство, своєю чергою, впливає i регулює управлінську діяльність. Звідси постає проблема нових ідей i практичних кроків у публічному управлінні, коли ціннісні аспекти культури виступають особливим механізмом, що зберігає все те позитивне, що було в державному управлінні в минулому та відтворює й утверджує сучасні світові й національні цінності публічної управлінської діяльності.

Відомий польський соціолог П. Штомпка, досліджуючи соціокультурні трансформаційні процеси суспільства як цілісної системи, до якої входить й управління цими процесами пише про так звані «травматогенні зміни», що можуть негативно впливати як на управлінця окремо, так i публічне управління як структурну складову держави. Він виділяє такі моменти: достатньо швидкісні, надто різкі й неочікувані зміни, що відбуваються протягом короткого часу; такі зміни у соціальному просторі зачіпають усі галузі життєдіяльності суспільства; вони можуть безпосередньо торкатися цінностей певних соціальних груп, їх переконань, способу життя, правил поведінки тощо; все це може призвести до глибокого соціально-політичного конфлікту у суспільстві й державі [4, с. 474].

Деяким чином сучасний стан України відповідає цим попередженням П. Штомпки. I для того щоб вирішити такі болючі проблеми української дійсності - анексія Криму, війна на Донбасі, внутрішні політичні протиріччя, важкий соціальноекономічний стан населення, подекуди управлінський непрофесіоналізм, регіональні відмінності тощо необхідний консенсусний, заснований на здоровій управлінській культурі підхід виходу з цієї кризи. А він передбачає врахування інтересів різних соціальних груп, виважені продуктивні соціальні реформи, вироблення цінностей миру, політичну толерантність, матеріальний i духовний достаток громадян, вдосконалення управлінських структур, подальше формування управлінської культури, політичну волю керівництва до впровадження позитивних змін, соціальний діалог суспільства й держави тощо.

Процес формування управлінської культури зумовлює поміж іншим розробку і практичне втілення дієвих механізмів 
упорядкування управлінської й політичної взаємодії політиків, влади, суспільства і держави, управлінських інститутів. При цьому, дозволяє виробляти в управлінській культурі ознаки певної міри невтручання держави у громадянські практики та ініціативу громадських інституцій суспільства. Результативне вирішення таких проблем лежить у площині формування здорової управлінської культури, коли публічний управлінець, політик, представник влади розуміє й усвідомлює своє покликання (за М. Вебером), а політико-управлінську діяльність втілює як плідну професійну роботу на користь держави i суспільства.

Українські науковці з НАДУ при Президентові України у своєму дослідженні [2] розробили ряд соціокультурних показників, які безпосередньо можуть впливати на публічне управління. Проаналізуємо їх.

1. Сформована управлінська культура сприяє виробленню навичок та умінь, які найперше пов'язані 3 управлінськими проблемами контактувати і знаходити спільну мову 3 людьми, колективами та організаціями. При цьому «особливо важливі комунікативні навички ділового та публічного спілкування, підтримання позитивного іміджу й професійного авторитету» [2, c. 7].

2. Бажано, щоб була спеціальна фахова підготовка стосовно інформаційно-аналітичної та технічної роботи 3 комп'ютером, документами, законами, актами «відповідно до формальних регламентів та неформальних процедур» [2, с. 7].

3. Професійно-організаційні здібності ефективного управління людьми, де дуже важливо «відстоювати та проводити «загальну волю» в тому чи іншому розумінні, а також здатність працювати в команді, чітко ставити завдання та вимагати їх виконання» [2, с. 7].

4. Професіоналізм і управлінська культура політиків, службовців публічного управління, представників влади мають грунтуватися на певних морально-етичних, правових, соціальнополітичних і культурних принципах, що відповідають нормам виховання, суспільної моралі й поведінки. При цьому зростає роль у публічному управлінні таких складових, як результативність управлінської роботи, ефективність кадрової 46 
політики, підзвітність громадянському суспільству, здорові відносини у колективі тощо.

Отже, правильним буде вважати, що управлінська культура $\epsilon$ базовою основою впровадження та подальшого застосування як класичних досягнень управлінської думки, так і нових та новітніх технологій у публічному управлінні. Набуті соціокультурні компетентності та їх застосування у практичному управлінні сприятимуть вдосконаленню складної та динамічної структури державно-управлінських відносин. Навіть більше, думається, що вони своїми можливостями «сприятимуть підвищенню ефективності та дієвості державного-управлінського апарату; збільшенню довіри народу до влади, яка проголошує та стверджує принципи відкритості, верховенства права, законності, політичної неупередженості, демократії» [5, с. 141].

\section{Література:}

1. Вебер М. Избранное. О некоторых категориях понимающей социологии (Лики культуры) / отв. ред. и сост. Я. М. Вебер. Москва: Юрист, 1994. 702 с.

2. Державно-управлінські відносини в Україні: стан і шляхи вдосконалення: наук.-метод. розробка / авт. кол.: Е. А. Афонін, В. В. Голубь, Л. В. Гонюкова та ін.; за заг. ред. В. А. Ребкало, В. А. Шахова. Київ: НАДУ, 2012. 48 с.

3. Пилипенко В., Сапєлкіна О., Чепурко Г. Модернізація: теорія, практика, цивілізаційний вимір / відп. ред. Ю. О. Привалов. Київ-Львів: Ліга-Прес, 2016. 130 с.

4. Штомпка П. Социология. Анализ современного общества / пер. с польск. С. М. Червонной. Москва: Логос, 2005. $664 \mathrm{c}$.

5. Шутовська 3. Формування соціокультурних компетентностей державного службовця в умовах сталого розвитку. Україна 2030: публічне управління для сталого розвитку: матеріали наук.-практ. конф.: у 3-х т. / за заг. ред. А. П. Савкова, М. М. Білинської, О. М. Петроє. Київ: НАДУ, 2020. Т. 1. C. $138-141$. 